\title{
Materials to the Zygnemaceae of Poland. IV. Spirogyra australica Czurda - a species new in Poland
}

\author{
JOANNA Z. KADEUBOWSKA
}

\author{
Department of Algology, Institute of Environmental Biology, \\ Łódź University, Banacha 12/16, 90-237 Łódź, Poland \\ (Received: November 22, 1988. Revision accepted: August 4, 1989)
}

\begin{abstract}
Spirogyra australica Czurda 1932 was identified in a sample taken from a small pond in the Arboretum in Rogowo (Skierniewice Voivodship) on June 17, 1986. The diagnosis of this species has been supplemented with data on the width of vegetative cells, the dimensions of zygotes and the development of the conjugation tube. $S$. australica has been reported in Europe only in the Federal Republic of Germany (Bock and Bock 1956, Arch. Hydrobiol. 52). The figures presented in this report are the first graphic documentation of this species.
\end{abstract}

Key words: Spirogyra, taxonomy

Möbius described algae from the vicinity of Brisbane, Australia, in 1892. He gave a description of an alga which he identified as $S$. calospora Cleve. This description was the basis on which Czurda created a new species, Spirogyra australica. In the justification for this, Czurda (1932 pg. 157) gives "Obgleich unvollständig bekannt, ist diese von Möbius 1892 gesehene, als Sp. protecta bezeichnete Probe als eigene Art hinreichend begründet" (the quote should read $S p$. calospora, not $S p$. protecta, in agreement with the data of Möbius (1892 pg. 439)).

The formation of this taxon is justified because the sculptures of $S$. australica and $S$. calospora zygote walls are different. S. australica zygote walls are characterized by a single-layered, smooth exospore and punctated mesospore while the exospore of $S$. calospora is double-layered, its inner layer is scrobiculate, and the mesospore is smooth. 
B ock and B ock (1956) reported S. australica from the locations of Kranser and Steigerwald, however, they did not provide drawings or an exact description.

The lack of drawings was the probable reason why this species was not included in the monographies by Transeau (1951), Randhawa (1959) and Kadłubowska $(1972,1984)$.

S. australica Czurda was identified in a sample taken on June 17, 1986 from a small pond in the Arboretum in Rogowo (Skierniewice Voivodship). Its vegetative and generative stages were the basis for this identification. Table 1 gives the characteristics of $S$. australica according to Czurda (1932), Bock and Bock (1956) and this author's observations.

As can be seen from the comparison of characteristics (Table 1), Czurda's diagnosis should be supplemented by data on the width of vegetative cells, zygote dimensions and formation of the conjugation tube.

\section{Table 1}

A comparison of Spirogyra australica characteristics according to Czurda (1932) Bock and Bock (1956) and this author's observations

\begin{tabular}{|c|c|c|c|c|}
\hline \multirow{2}{*}{ Characteristic } & \multirow{2}{*}{ Czurda } & \multicolumn{2}{|c|}{$\begin{array}{c}\text { Bock and Bock } \\
\text { locality }\end{array}$} & \multirow{2}{*}{$\begin{array}{c}\text { Author's } \\
\text { observations }\end{array}$} \\
\hline & & Krenser & Steigerwald & \\
\hline $\begin{array}{l}\text { Type of } \\
\text { conjugation }\end{array}$ & scalariform & no data & no data & scalariform \\
\hline $\begin{array}{l}\text { Female } \\
\text { gametangium }\end{array}$ & $\begin{array}{l}\text { slightly } \\
\text { inflated }\end{array}$ & no data & no data & $\begin{array}{l}\text { cylindric } \\
\text { or slightly } \\
\text { inflated }\end{array}$ \\
\hline $\begin{array}{l}\text { Copulation } \\
\text { canal }\end{array}$ & no data & no data & no data & $\begin{array}{l}\text { formed by } \\
\text { both } \\
\text { gametangia }\end{array}$ \\
\hline $\begin{array}{l}\text { Zygote } \\
\text { shape }\end{array}$ & $\begin{array}{l}\text { long-axial } \\
\text { ellipsoid }\end{array}$ & no data & no data & $\begin{array}{l}\text { ellipsoid - } \\
\text { rarely } \\
\text { egg-shaped }\end{array}$ \\
\hline $\begin{array}{l}\text { Zygote dimensions } \\
\text { in } \mu \mathrm{m}\end{array}$ & $\begin{array}{l}30-36 \times \\
64-70\end{array}$ & $\begin{array}{l}\text { length } \\
58-64\end{array}$ & $\begin{array}{l}27-34 \times \\
54-74\end{array}$ & $\begin{array}{l}36.6-40.0 \times \\
55.2-84.0\end{array}$ \\
\hline Exospore & $\begin{array}{l}\text { smooth, } \\
\text { thin }\end{array}$ & no data & no data & $\begin{array}{l}\text { smooth, } \\
\text { thin, } \\
\text { colorless }\end{array}$ \\
\hline Mesospore & punctate & no data & no data & $\begin{array}{l}\text { punctate } \\
70-90 \text { points } \\
\text { in } 100 \mu \mathrm{m}\end{array}$ \\
\hline $\begin{array}{l}\text { Number of } \\
\text { chromatophores }\end{array}$ & 1 & no data & no data & 1 \\
\hline End walls & replicate & no data & no data & replicate \\
\hline $\begin{array}{l}\text { Width of vege- } \\
\text { tative cells in } \mu \mathrm{m}\end{array}$ & 27 & up to 32 & $24-25$ & $28.6-35.0$ \\
\hline
\end{tabular}


PLATE I
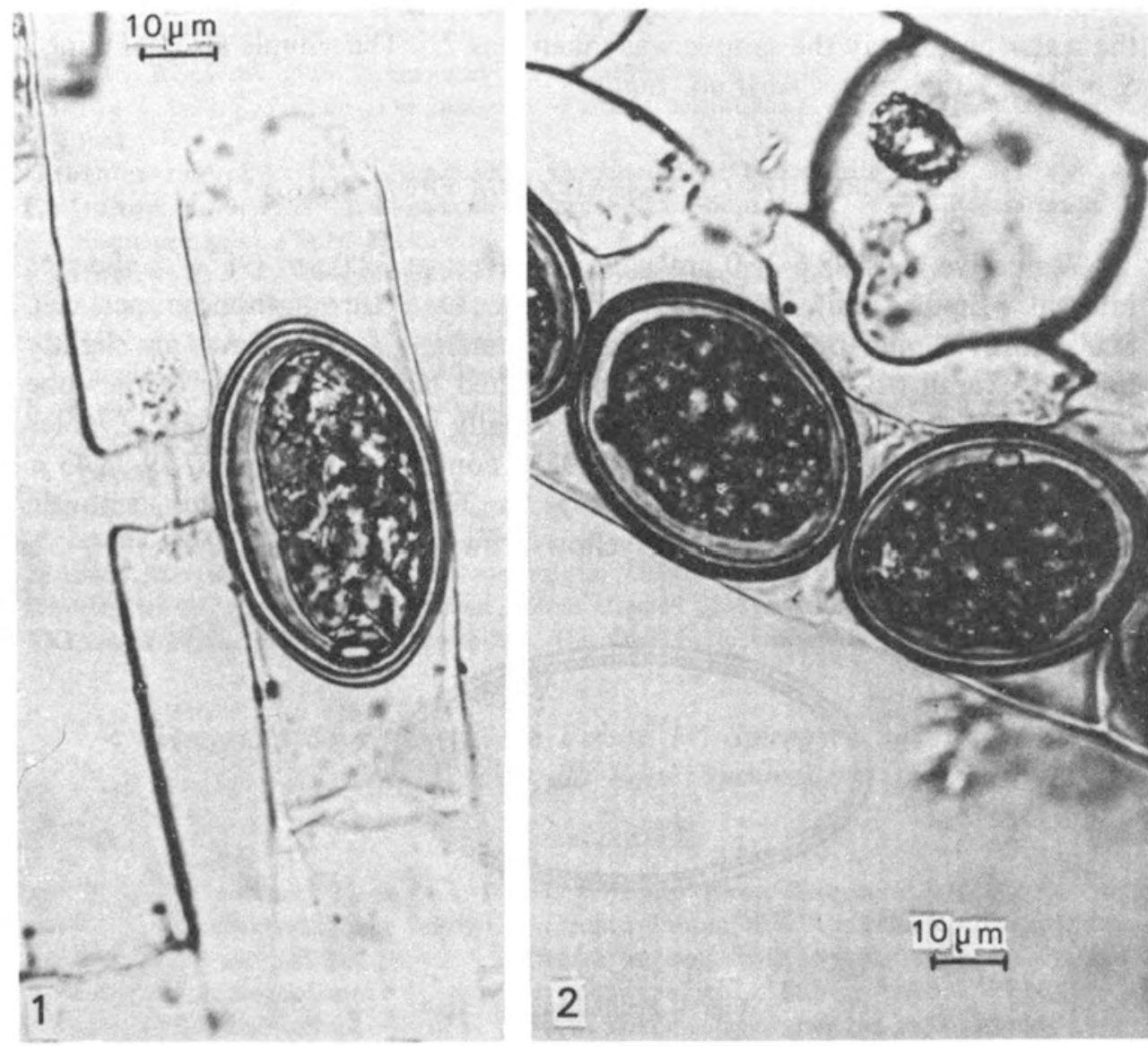

$10 \mu \mathrm{m}$

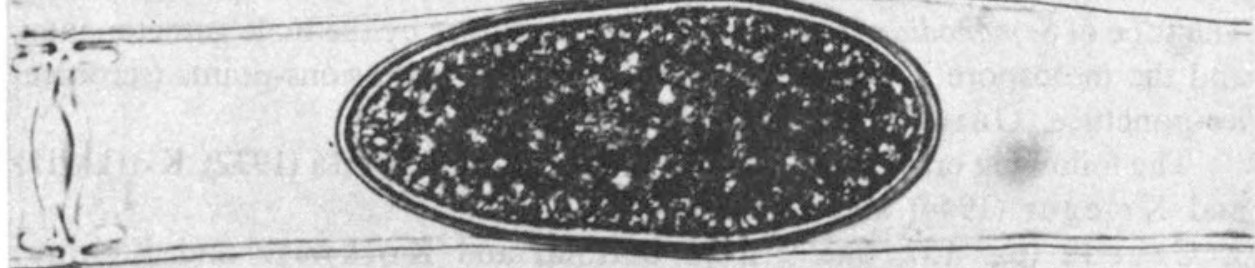

3

Figs. 1-3. Spirogyra australica: 1 - scalariform conjugation, tube formed by both gametangia, gametangia cylindric and zygospore ellipsoid; 2 - female gametangia inflated on the inner side; 3 - zygospore ovoid, conjugation tube invisible 
S. australica is species new to Poland (Kadłubowska 1986). The $\mathrm{pH}$ of the water on the day the sample was taken was 7.6. The sample also contained $S$. weberi Kütz. and Chara sp. thalli.

\section{DESCRIPTION OF S. AUSTRALICA FROM ROGOWO}

Vegetative cells $28.6-35.0 \mu \mathrm{m}$ wide, on average $32.0 \mu \mathrm{m}(95 \%$ confidence interval 31.6-32.4 $\mu \mathrm{m})$. Replicate end walls. One chromatophore per cell. Scalariform conjugation (Fig. 1). Female gametangia not inflated or slightly inflated overall (to $40 \mu \mathrm{m}$ ), very rarely inflated only on the side of the tube (Fig. 2). The conjugation tube is formed equally by both gametangia. Zygotes are ellipsoid, 33.6-40.0 $\times 55.2-84.0 \mu \mathrm{m}(95 \%$ confidence interval $37.79-38.43 \times$ $\times 74.5-76.0 \mu \mathrm{m}$ ), rarely egg-shaped (Fig. 3). The exospore is thin, smooth, colorless. The mesospore is thin, yellow-brown, punctate (Fig. 4).

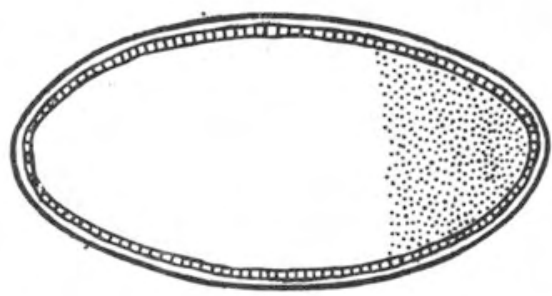

$\stackrel{10 \mu \mathrm{m}}{\longmapsto}$

Fig. 4. Sculpturing of zygote

Spirogyra australica is similar to $S$. monodiana Gauthier-Lièvre but differs from this species by the shape of its conjugation tube and mesospore thickness. The tube of $S$. monodiana is formed by the most part by the male gametangium, and the mesospore is 6-7 $\mu \mathrm{m}$ thick with delicate depressions-points (scrobiculée-ponctuée, Gauthier-Lièvre 1965 pg. 176).

The following errors are found in the works of Czurda (1932), Kolkwitz and Krieger (1944) and Langer (1934):

1. Czurda (pg. 157, line 9 from bottom) and Kolkwitz and Krieger (pg. 458, line 20 from top) give S. protecta instead S. calospora;

2. Figures 191 and 192 in Langer (pg. 1282) refer to S. austriaca, not S. australica.

\section{Acknowledgement}

This study received financial support from the Institute of Botany of the Polish Academy of Sciences. 


\section{REFERENCES}

Bock O., Bock W., 1956. Zygnemales aus Unterfranken. Arch. Hydrobiol. 52: 406-448.

Czurda V., 1932. Zygnemales. Die Süsswasser-Flora Mitteleuropas. 9. A. Pascher (ed.). G. Fischer, Jena.

Gauthier-Lièvre L., 1965. Zygnémacées Africaines. Beih. Nova Hedwigia 20: 1-210.

Kadłubowska J. Z., 1972. Zygnemales. Flora Słodkowodna Polski. 12 A. K. Starmach, J. Siemińska (eds.), PWN, Kraków.

Kadłubowska J. Z., 1984. Conjugatophyceae I. Zygnemales. Süsswasserflora von Mitteleuropa.

16. Ettl H., Gerloff J., Heynig H., Mollenhauer D. (eds.). G. Fischer, Jena.

Kadłubowska J. Z., 1986. Materiały do Flory Polski. Zygnemales. Streszczenia referatów 47

Zjazdu Polskiego Towarzystwa Botanicznego, Łódź.

Kolkwitz R., Krieger H., 1944. Zygnemales. Rabenhorst's Kryptogamen-Flora von Deutschland und der Schweiz. 13. 2. 4. Akademische Verlagsgesellschaft Becker u. Erler Kom.-Ges., Leipzig.

Langer S., 1934. A Spirogyrák monografikus feldolgozása, különös tetinkettel nagymagyarorszagra. Folia Cryptog. 10: 1254-1306.

Möbius M., 1892. Australische Süsswasseralgen. 75: 421-450.

Randhawa M. S., 1959. Zygnemaceae. Indian Council of Agricultural Research, New Delhi. Transeau E. N., 1951. The Zygnemaceae. The Ohio State University Press, Columbus.

\section{Materialy do Zygnemaceae Polski. IV. Spirogyra australica Czurda nowy dla Polski gatunek}

\section{Streszczenie}

W próbie pobranej 17 czerwca 1986 r. z małego stawu Arboretum w Rogowie (woj. skierniewickie) zidentyfikowano Spirogyra australica Czurda 1932. Uzupełniono diagnozę tego gatunku danymi dotyczącymi szerokości komórek wegetatywnych, wymiarów zygot i wykształcenia kanału koniugacyjnego. S. australica podawana jest z Europy tylko z RFN (Bock i Bock 1956). Zamieszczone ryciny są pierwszą dokumentacją graficzną tego gatunku. 